\title{
エリクソン磁気冷凍用複合型磁気作業物質
}

\author{
橋本魏洲，葛原 徹，佐橋政司*，猪俣浩一郎*，

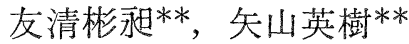 \\ 東京工業大学理学部応用物理学科 東京都目黑区大岡山 \\ *(姝)東芝総合研究所金属セラミック材料研究所 神奈川県川崎市幸区東芝町1 \\ **九州大学教着部物理教室 福岡市中央区六本松4-2-1
}

(1986年 7 月28日受理)

\section{Investigation on a Complex Type of Magnetic Refrigerants for the Ericsson Magnetic Refrigeration}

\begin{abstract}
Takasu Hashimoto, Tohru Kuzuhara, Masashi Sahashi*, Koichiro Inomata*, Akihisa TomokIYo** and Hideki YAYAMA**

Dept. of Applied Physics, Tokyo Institute of Technology, Oh-okayama, Meguro, Tokyo

*Research and Development Center, Toshiba Co., Toshiba-cho, Saiwai-ku, Kawasaki, Kanagawa

**Dept. of Physics, College of General Education, Kyushu University, Chuo-ku, Fukuoka
\end{abstract}

(Received July 28, 1986)

\section{Synopsis :}

A complex type of magnetic refrigerant for the Ericsson cycle has been investigated. For the magnetic refrigerant in the temperature range above $\sim 15 \mathrm{~K}$ we have to use the ferromagnetic material, which has the internal magnetic field to arrange its spin system as far as using a magnetic field of $\sim 6 \mathrm{~T}$, because of increasing of the thermal excitation energy for spins $\sim k T$. Moreover, we have to select the Ericsson cycle instead of the Carnot cycle usually used in the low temperature range below $\sim 15 \mathrm{~K}$, since the lattice entropy of a solid material in this range is not negligible in comparison with the magnetic entropy.

In order to form a high efficient Ericsson cycle that includes two kinds of iso-magnetic field processes, a new severe condition is required for the magnetic refrigerant, that is, the magnetic entropy change $\Delta S_{J}$ is constant in the refrigeration range. This condition, however, can not be satisfied by an usual homogeneous ferromagnetic substance.

In the present paper we first made clear from the theoretical analysis that the complex of the ferromagnetic materials, for instance $\left(\mathrm{ErAl}_{2}\right)_{0.312}\left(\mathrm{HoAl}_{2}\right)_{0.198}\left(\mathrm{Ho}_{0.5} \mathrm{Dy}_{0.5} \mathrm{Al}_{2}\right)_{0.490}$, well satisfies the above condition.

On the basis of the analysis we have prepared a complex consisted of several $R \mathrm{Al}_{2.15}$ compound layers with different rare earths $R$, such as $\left(\mathrm{ErAl}_{2.15}\right)_{0.312}\left(\mathrm{HoAl}_{2.15}\right)_{0.198}\left(\mathrm{Ho}_{0.5} \mathrm{Dy}_{0.5}\right.$ $\left.\mathrm{Al}_{2.15}\right)_{0.490}$. For the complex we determine the magnetic entropy change $\Delta S_{J}$ and the entropy $S$ from the specific heat measurement.

From these results we can conclude that the layer type complex material is most hopeful not only for the Ericsson type magnetic refrigerant but also for the regenerative material.

\section{1. 序}

磁気熱量効果を利用した磁気冷凍においては, 現 在, 低温域のカルノー方式を用いた磁気冷凍の研究開
発が先行しているが1，これは，この方式の原理，接 構, 動作が非常に単純なこと，および，近い将来にお ける低温域の高効率小型冷凍機の需要増に対する期待 とに負うところが大きい。 
しかしながら，冷凍域を $20 \mathrm{~K}$ 近く，あるいはそれ以 上に，拡大することは，通常の常磁性体と $6 \mathrm{~T}$ 程度の 磁場を用いる限り，スピン系の熱励起エネルギー〜 $k T$ ( $k$ : ボルツマン定数, $T$ : 温度) が, スピン準 位の外磁場 Bによる分裂幅 $g \mu_{B} B\left(g: g\right.$ 因子, $\mu_{B}$ : ボーア磁子）上り大きくなるので, 現在のカルノー方 式では不可能である。もちろん，現在多用されている 等方的弱反強磁性体 $\mathrm{Gd}_{3} \mathrm{Ga}_{5} \mathrm{O}_{12}(\mathrm{GGG})^{2)}$ の代りに, $g$ 因子に大きな異方性を持っ $\mathrm{Dy}_{3} \mathrm{Al}_{5} \mathrm{O}_{12}(\mathrm{DAG})^{3)}$ の 容易軸方向を利用寸るといら便法もある。しかしこの 場合も $\mathrm{Dy}^{3+}$ のスピンが $1 / 2$ であるため, 使用可能な 磁気エントロピー変化 $\Delta S_{J}$ もそれ程大きくなく, そ の上, $20 \mathrm{~K}$ 近くでは格子エントロピー $S_{L}$ も無視でき なくなるので), 特に熱源である高温流体と低温流体 との混合損失の大きい磁性体移動型では, 大きな冷凍 出力が得られなくなる。

磁気エントロピー $S_{J}$ に比較して $S_{L}$ が無視できな い, すなわち $S_{J} \leq S_{L}$ の関倸が成立する領域において は，カルノーサイクルの代りに, Fig. 1 に示すよう な, 二つの等温過程の間を二種の等磁場過程で結ぶエ

リクンンサイクルが威力を発揮する。このサイクル は, 蓄冷器の助けを借り, 等温磁化で放熱した後の等 磁場過程 $\left(\mathrm{B}_{E} \rightarrow \mathrm{C}_{E}\right)$ において, スピン系 $S_{J}(T, B)$ の温度変化分のみならず, $S_{L}(T)$ の温度変化分をも

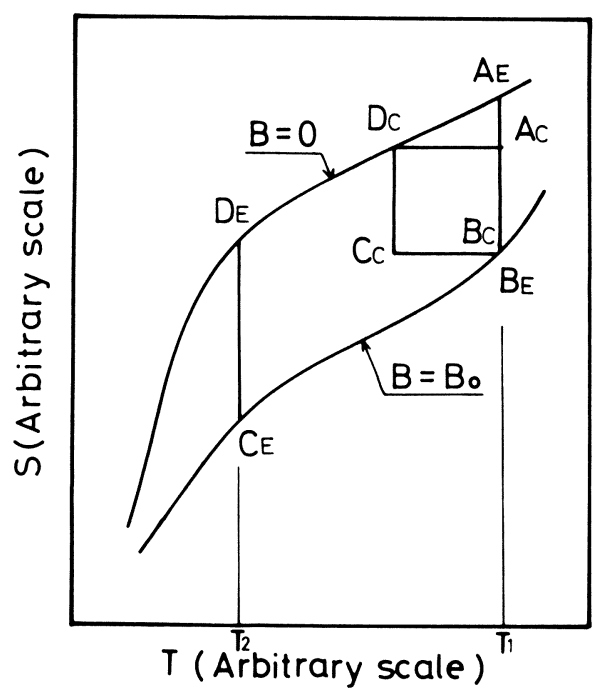

Fig. 1 The Carnot cycle $\left(\mathrm{A}_{C} \mathrm{~B}_{C} \mathrm{C}_{C} \mathrm{D}_{C}\right)$ and the Ericsson cycle $\left(\mathrm{A}_{E} \mathrm{~B}_{E} \mathrm{C}_{E} \mathrm{D}_{E}\right)$ shown on a schematic entropy-temperature diagram.
除去し, 磁性体の温度を冷凍温度 $\left(T_{2}\right)$ に迄下げ, 吸 熱過程 $\left(\mathrm{C}_{E} \rightarrow \mathrm{D}_{E}\right)$ 後の等磁場過程 $\left(\mathrm{D}_{\boldsymbol{E}} \rightarrow \mathrm{A}_{\boldsymbol{E}}\right)$ では, 先に蓄冷器が除去したエントロピーを再び磁性体に戻 し, 出発時の状態へ返し 1 サイクルが完結するような ものである。

本研究は, 磁気冷凍の冷凍域桩大に不可欠な蓄冷方 式の研究の第一歩として, 磁気作業物質の研究を行っ たものであり，特にエリクンン用の磁気作業物質とし て, 複合型強磁性作業物質が最も有効であることを理 論的, 実験的に明らかにし, 今後の研究開発方向を示 唆すると同時に，このような複合化物の新たな分野へ の応用についても言及したものである。

\section{2. 理論的背景 ${ }^{5}$}

我々が冷凍に使用可能な磁気エントロピー変化量 $\Delta S_{J}$ は, 外磁場 $B$ によるスピン準位の分裂幅 $g \mu_{B} B$ とスピンの熱励起エネルギー $k T$ との比によって決 るが， $6 \mathrm{~T}$ 程度の外磁場と $g$-因子が 2 で磁気的相互 作用が微弱なスピン系を使用する限り，〜15K以上で は，冷凍を行うに充分な $4 S_{J}$ は得られない。さらに $g_{/ /}=\sim 19, g_{\perp}=\sim 0.5$ である $\mathrm{Dy}^{3+}$ イオンを含み, 単軸異方性を持つ化合物常磁性体を使用するという便 法を講じたとしても，たかだか $20 \mathrm{~K}$ がその限界であ る。

それ故〜 $15 \mathrm{~K}$ 以上では，スピンを強磁性的に整列さ せようとする磁気的相互作用

$$
\leadsto=-2 \sum_{i>j} \lambda_{i j} \boldsymbol{J}_{i} \cdot \boldsymbol{J}_{j}-g \mu_{B} \sum_{i} \boldsymbol{J}_{i} \cdot \boldsymbol{B}
$$

を持つ磁性体を使用しなければならない。ここでJは スピンを表わし， $\lambda_{i j}$ は磁気的相互作用 パラメター で, $\lambda_{i j}>0$ である。このような磁性体の $\Delta S_{J}(T, B)$ は, 先の論文 ${ }^{4)}$ に示されたようにキュリー温度 $T_{C}$ 近 傍で鋭いピークを作る。その典型例として，等方的三 次元强磁性体の代表である EuS の $\Delta S_{J}$ が，Fig. 2 に示されている。このような温度特性は, 単一の磁性 イオンを含む場合のみでなく，多種のイオンすなわち 多種の $J$ を含み, 多くの $\lambda_{i j}$ が存在する系であって も, 均質な磁性体の場合には, 必ず現われる特性であ る。

一方, 二つの等磁場過程を含み, カルノー効率を満 すような理想的エリクンンサイクルを構成するために は，Fig. 1 を参照すれば明らかなように，磁性体が具 備しなければならない特性として,「強磁場および零 磁場中の二つの等磁場過程 (Fig. 1 では $\mathrm{B}_{E} \rightarrow \mathrm{C}_{E}$ お よび $\mathrm{D}_{E} \rightarrow \mathrm{A}_{E}$ 過程) の各温度における放熱 $\left(\mathrm{B}_{E} \rightarrow\right.$

Vol. 21 No. 5 (1986) 
$\left.\mathrm{C}_{E}\right)$ および吸熱量 $\left(\mathrm{D}_{E} \rightarrow \mathrm{A}_{E}\right)$ は常に等しい」ことが 要求される。これは言い換えると, サイクルを構成す る温度範囲で, Fig. 2 中に点線で示したように, $\Delta S_{J}$ の温度依存性がないことを磁気作業物質の特性として 要求しているのである。

しかし上記の特性は, 先に述べた均質強磁性体では 全く満し得ないものである。このようなサイクルから の要請と磁性体の特性との差違に対処する手段とし て, 幾つかの異った $\Delta S_{J}(T, B)$ を持つ磁性体を用い, 個々の特性をそのまま生かし， $\Delta S_{J}=$ 一定の特性を持 つような複合化物を作る方法が考案され5), これが本 研究の原点となった。

このような複合化物を作製するためには，固溶体の 組成制御によって, キュリー温度 $T_{C}$ を任意に変える ことができる磁性体系列が必要である。本研究では, 我々が先にその特性を明らかにした $R \mathrm{Al}_{2}$ 系が選ばれ $た^{6)}$ 。この物質は, Fig. 3 にその $\Delta S_{J}$ が示されてい るように, $\mathrm{ErAl}_{2}$ から $\mathrm{DyAl}_{2}$ まで全域で固溶体を作 り, $T_{C}$ は $15 \mathrm{~K}$ から $70 \mathrm{~K}$ の範囲で任意に変化させる ことが可能な系列であり, 本研究には, 最も適した強 磁性体系列の一つであると考えられるものである。

複合化物としては, Fig. 4 に示すような層状構造 は選ばれたが，このような構造は，「臨界温度近傍に おいて, 著しく長くなるスピンの相関距離以上の長周 期で組成変化させると, 層を構成する磁性体個々の特 性をそのまま保つことができるであろう」との推測か ら選択されたものである。一例として， $R \mathrm{Al}_{2}$ から， $\mathrm{Er} \mathrm{Al}_{2}, \mathrm{HoAl}_{2},\left(\mathrm{Ho}_{0.5} \mathrm{Dy}_{0.5}\right) \mathrm{Al}_{2}$ の 3 種の化合物を選 び,これ等のモル比を $0.312: 0.198: 0.490$ にして, Fig. 4 に示すような層状の複合焼結体を作った場合

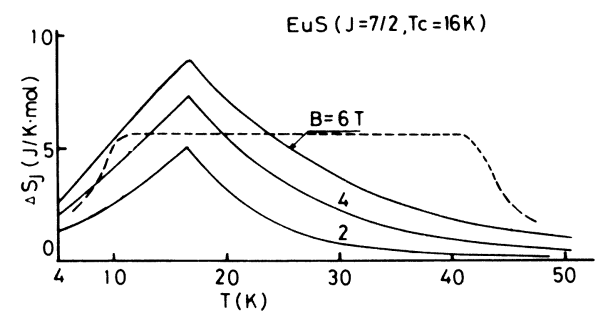

Fig. 2 Temperature dependence of the magnetic entropy change $\Delta S_{J}$ of EuS obtained by using the molecular field approximation. The dotted line shows the temperature dependence of $\Delta S_{J}$ suitable for the $\mathrm{Er}$ icsson cycle.

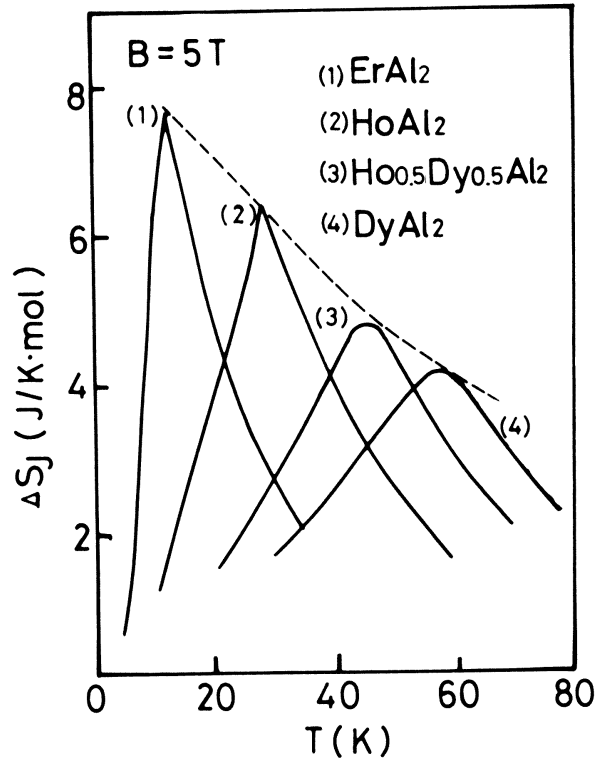

Fig. 3 Magnetic entropy change $\Delta S_{J}$ of several compounds $\left[(1) \mathrm{ErAl}_{2}\right.$, (2) $\mathrm{HoAl}_{2}$, $\left(\mathrm{Ho}_{0.5} \mathrm{Dy}_{0.5}\right) \mathrm{Al}_{2}$, (4) $\left.\mathrm{DyAl}_{2}\right]$ in the $\mathrm{RAl}_{2}$ system induced by a magnetic field of $5 \mathrm{~T}$.

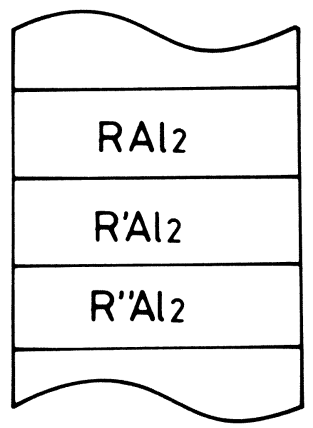

Fig. 4 Schematic configuration of layer type complex magnetic refrigerant.

に得られると予想される $4 S_{J}(T, B)$ を示すと, Fig. 5 の如くなる。この結果は, エリクソンサイクルに適し た温度依存性を持つ $\Delta S_{J}$ が得られることを示してお り，このような方法がエリクソン用磁気作業物質の作 製に非常に有効な方法であることを明瞭に示したもの である。

本研究では, このような理論的予測が, 実現可能な ものであることを実証するのがその目的である。

\section{3. 実 験}

実用的見地から眺めると，焼結体を磁気作業物質に 
使用する場合に問題となるのは，その充堤率である。 $R \mathrm{Al}_{2}$ 化合物粉体の単純な焼結では高密度焼結体が得 られないので, 組成を $R \mathrm{Al}_{2+\delta}$ とし, $R \mathrm{Al}_{2}$ 粒間にあ る融点の低い $R \mathrm{Al}_{3}$ のみを融解し固化する，いわゆる 液相焼結法が用いられた。その充填率の $\delta$ 依存性を示 すと Fig. 6 のようになり,この結果から ${ }^{7)}$, 本研究で

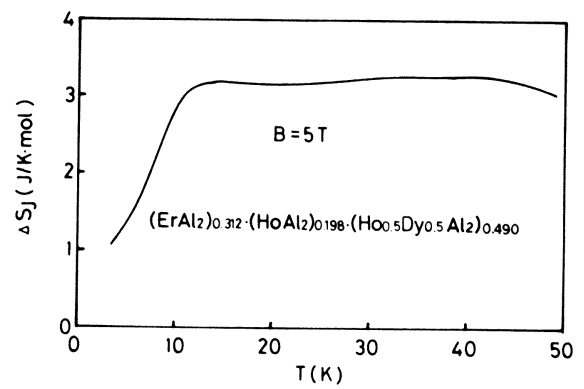

Fig. 5 Temperature dependence of the magnetic entropy change $\Delta S_{J}$ expected for the layer type magnetic refrigerant $\left(\mathrm{ErAl}_{2}\right)_{0.312}$ $\left(\mathrm{HoAl}_{2}\right)_{0.198}\left(\mathrm{Ho}_{0.5} \mathrm{Dy}_{0.5} \mathrm{Al}_{2}\right)_{0.490}$ calculated from the experimental results shown in Fig. 3 .

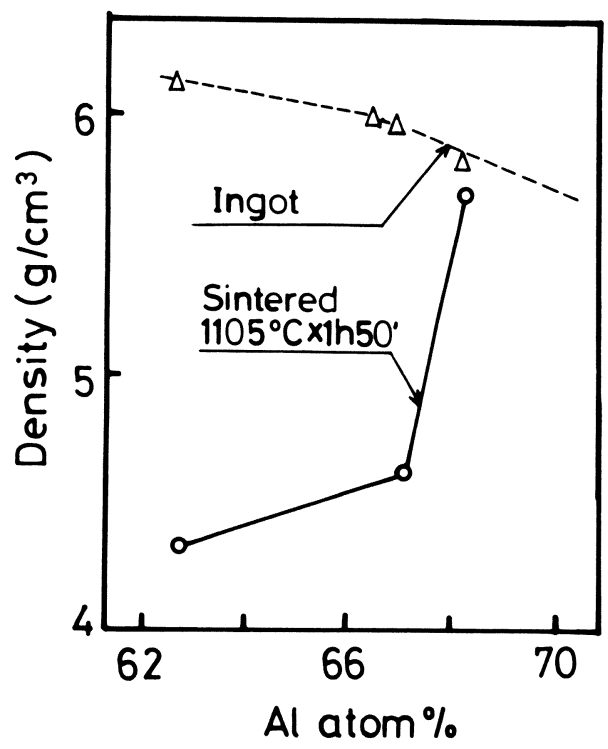

Fig. 6 Composition dependence of the density of the Dy- $\mathrm{Al}$ system produced by press and sintering method, along with the densities of ingots.

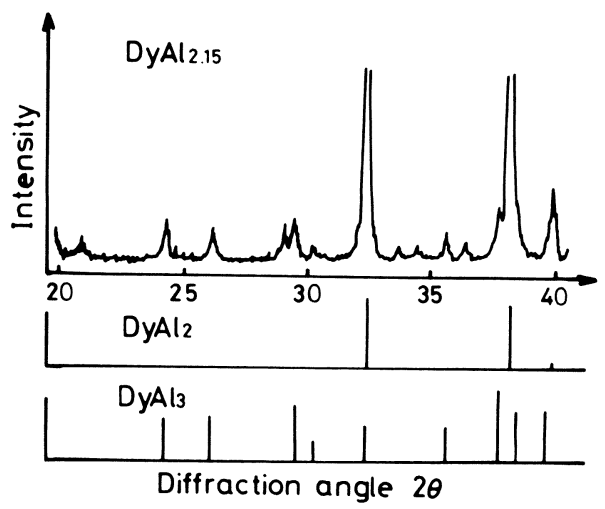

Fig. 7 X-ray powder diffraction patterns of Dy $\mathrm{Al}_{2.15}$ compared with those of $\mathrm{DyAl}_{2}$ and $\mathrm{DyAl}_{3}$.

は $R \mathrm{Al}_{2.15}$ 系を使用することが決定された。

$R \mathrm{Al}_{2.15}$ 系磁性材料は, $\mathrm{Ar}$ 雾囲気中でアーク溶解 法を用いて合成し, 均質化を計るために溶解, 粉砕が 数回繰り返され, 最終的にはボールミルにて粉砕し, $\sim 3 \mu \mathrm{m}$ 程度の均質微粉末が得られた。

合成された粉末試料の $\mathrm{X}$ 線回折実験が行なわれ, 回 折パターン中には, 鋭い $R \mathrm{Al}_{2}$ の回折線と, $R \mathrm{Al}_{3}$ に 相当すると考えられる弱い回折線とが重冨しているこ とが確認された (Fig. 7)。

このようにして得られた幾種かの化合物粉末を層状 に積み重极, 圧縮, 焼結を行なった後に層間剝離が起 きないようにするために，次のような方式が用いられ た。第一層は $\mathrm{ErAl}_{2.15}$ 粉末とアセトンとの混合体(ス ラリー) をプレス容器中に入れ平坦層を作り, 次に他 の化合物粉末, 例えば $\mathrm{HoAl}_{2.15}$ とアセトンとの混合 体を乗せ, さらに次の層を同様に作るという手法を用 い, Fig. 4 に示したと同様な層状構造を作った。

本研究では, $\mathrm{ErAl}_{2.15}, \mathrm{HoAl}_{2.15},\left(\mathrm{Ho}_{0.5} \mathrm{Dy}_{0.5}\right)$ $\mathrm{Al}_{2.15}$ の比を $0.312: 0.198: 0.490$ に選ばれたが,こ れは, $R \mathrm{Al}_{2.15}$ の詳細な磁気熱量特性が得られていな いので, $R \mathrm{Al}_{2}$ の結果を基に算定されたモル比である。

上で述べたと同様な方法で作られた層状構造物を $2.1 \times 10^{7} \mathrm{~kg} / \mathrm{m}^{2}$ の圧力で圧縮し, Ar 雾囲気中におい て 1 時間加熱した。燒結体を層に垂直な面で切断し, 電子線マイクロアナライザーで解析した 組成変化を Fig. 8 に示す。この結果は, 層間の約 $200 \mu \mathrm{m}$ の領域 で固溶体ができているが, その他の領域では, 初期の 
組成がそのまま保たれていることを明らかに示してい る。

このような試料のエントロピーの温度変化を求める ために，比熱測定が行なわれた。比熱測定には，断熱 容器中, 試料に一定電力を加え, その温度変化の時間 依存性をカーボングラス抵抗温度計で計測し，(dT/ $\mathrm{d} t)$ から比熱を求める方法が用いられた ${ }^{8)}$ 。計測の誤 差は，零磁場の場合 $2 \%$ 以下であることが，標準試料 ( $\mathrm{Pb}$ および $\mathrm{Cu})$ の測定から確認された。しかし磁場 中の測定の場合は，反磁場の補正が不充分であること から， 2 5\%の誤差が入ってくる。一般に強磁性体 に外磁場が加えられた場合，試料に有効に働く磁場 $B_{\mathrm{eff}}$ は外磁場 $B$ とは異り，次式で示されるように， 反磁場係数 $N$ と磁化 $M$ に依存する関数として与えら れる。

$$
B_{\mathrm{eft}}=B-N M
$$

ここでNは大きな形状依存性を持ち，例えば円筒の場 合は, 軸長 $l$ と半径 $r$ との比，( $r / l)$ の大きさによっ て, 0 から 1 の間で変化する。

この実験の場合には，もちろん外磁場は層面に平行 方向に加え， $N$ 小さくなるように工夫してあるが, 各層の $T_{C}$ が異るため $N$ が温度依存性を持つことにな り，正確な補正が行い得ないのである。したがって， 本研究では, 加えた外磁場の值をそのまま示してある が，実際の試料に対する有効磁場 $B_{\text {eff }}$ は，特に低温 域において数\%小さくなっていると考えられる。ただ

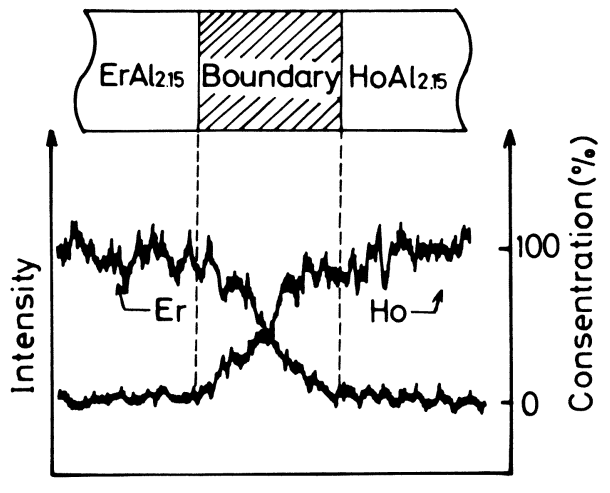

Position

Fig. 8 Composition dependence of a layer type sintered composite along the axis perpendicular to the layer obtained by an electron probe $\mathrm{X}$-ray micro analysis.
し,この䛊差の予測值は, 試料の形状から粗い近似を 用いて得られたものである。

\section{4. 結 果}

Fig. 9 には，0，1 および 5 Tの磁場中における複 合焼結磁性体 $\left(\mathrm{ErAl}_{2.15}\right)_{0.312} \cdot\left(\mathrm{HoAl}_{2.15}\right)_{0.198} \cdot\left(\mathrm{Ho}_{0.5}\right.$ $\left.\mathrm{Dy}_{0.5} \mathrm{Al}_{2.15}\right)_{0.490}$ の比熱が示されている。外磁場が零 の場合に現れている三つのピークは，複合化物を構成 している 3 種の化合物の相転移点における比熱異常に 対応している。これ等のキュリー温度 $T_{C}$ と $R \mathrm{Al}_{2}$ 系 における $T_{C}$ との比較が Table 1 に示されているが, 前者の $T_{C}$ が低温側へとずれている ${ }^{7)}$ 。

この理由については, 現在 $R \mathrm{Al}_{2}$ と混合している $\mathrm{RAl}_{3}$ の微視的構造が明らかにされていないので, 定 量的に議論することはできない。しかし現在までに見 いだされているいくつかの $R \mathrm{Al}_{3}$ 相においては，いず れの場合もスピン間の相互作用は, 弱い反強磁性的な ものである。また $\mathrm{RAl}_{2.15}$ 系の相転移は, Fig. 9 か ら見る限り特定の $T_{C}$ で明瞭に起っており, 系全体に 涉る強い協力現象が働いていると考えられる。このよ

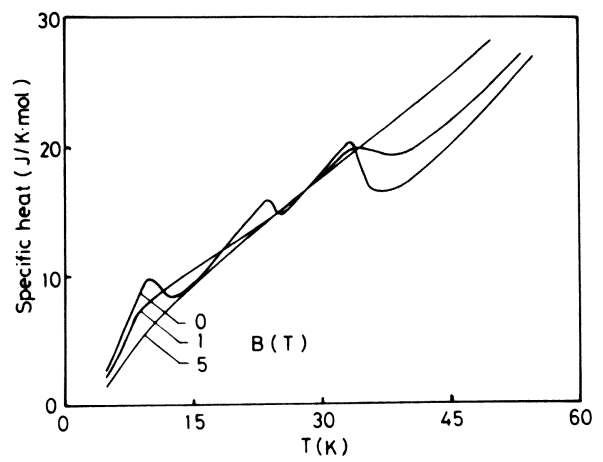

Fig. 9 Temperature dependences of the specific heat of the layer type sintered composite of $\left(\mathrm{ErAl}_{2.15}\right)_{0.312}\left(\mathrm{HoAl}_{2.15}\right)_{0.198}\left(\mathrm{Ho}_{0.5} \mathrm{Dy}_{0.5}\right.$ $\left.\mathrm{Al}_{2,15}\right)_{0.490}$ in several magnetic fields.

Table 1 Comparison between the Curie temperature $(\mathrm{K})$ of the $\mathrm{RAl}_{2}$ and the $R \mathrm{Al}_{2,15}$ system

\begin{tabular}{|c|c|c|c|}
\hline $\begin{array}{ll}\text { system } & R \\
\end{array}$ & $\mathrm{Er}$ & Ho & $\left(\mathrm{Ho}_{0.5} \mathrm{Dy}_{0.5}\right)$ \\
\hline$R \mathrm{Al}_{2}$ & 11.7 & 26.8 & 46.0 \\
\hline$R \mathrm{Al}_{2.15}$ & 10.0 & 25.9 & 33.2 \\
\hline
\end{tabular}


うな場合には， $R \mathrm{Al}_{2}$ 系と $R \mathrm{Al}_{3}$ 系とが，均質に混合 していると仮定してもよい。

このような系における $R \mathrm{Al}_{2}$ および $R \mathrm{Al}_{3}$ の濃度を $c$ および $(1-c)$ とし，分子場近似を用いて磁気モー メントを求め, これを $1 / \mathrm{k} T$ で展開し第一項のみをと るCurie-Weiss 則と同程度の近似度で $T_{C}$ を求める と

$$
\left.\begin{array}{rl}
T_{C}= & (2 z / 3 k)\left\{c^{2} \lambda_{11} J_{1}{ }^{2}\left(J_{1}+1\right)^{2}+(1-c)^{2} \lambda_{22} J_{2}{ }^{2}\right. \\
& \left(J_{2}+1\right)^{2}+2 c(1-c) \lambda_{12} J_{1}\left(J_{1}+1\right) J_{2}\left(J_{2}+\right. \\
& 1)\} /\left\{c J_{1}\left(J_{1}+1\right)+(1-c) J_{2}\left(J_{2}+1\right)\right\}
\end{array}\right\}
$$

と与えられる。ただし $J_{1}, J_{2}$ は $R \mathrm{Al}_{2}$ および $R \mathrm{Al}_{3}$ 領 域中のスピンを表わし， $\lambda_{11}, \lambda_{22}$ および $\lambda_{12}$ はそれぞれ $J_{1}-J_{1}, J_{2}-J_{2}$ および $J_{1}-J_{2}$ 間の磁気的相互作用係 数である。したがって, $\lambda_{11}>0, \lambda_{22}<0$ の場合, $\lambda_{12}$ が,

$$
\begin{aligned}
& 2 \lambda_{12}<\lambda_{11}\left\{(1+c) J_{1}\left(J_{1}+1\right) / c J_{2}\left(J_{2}+1\right)\right\} \\
& +\lambda_{22}\left\{(1-c) J_{2}\left(J_{2}+1\right) / c J_{1}\left(J_{1}+1\right)\right\}
\end{aligned}
$$

の条件を満すと系の $T_{C}$ は低下する。Table 1 の結果 は, 上の条件の反映にほかならないと考えられる。

エントロピー $S$ は, 熱力学的定義に基䃈を置くと,

$$
S=\int_{0}^{T}\{C(T, B) / T\}_{B} \mathrm{~d} T
$$

のように比熱 $C(T, B)$ から求めることができる。(4) 式を用いて Fig. 9 から計算された結果は, Fig. 10 に 示されている。この結果は, Fig. 10 に示すように, $40 \mathrm{~K}$ から $20 \mathrm{~K}$ 領域にわたって, $B=0$ および $5 \mathrm{~T}$ の二 つの等磁過程における磁気エントロピー差 $\Delta S_{J}$ が, ほぼ一定であることを示しており，このような磁気作 業物質の構成法が，エリクンン用作業物質作成に非常 に有効であることを実証している。

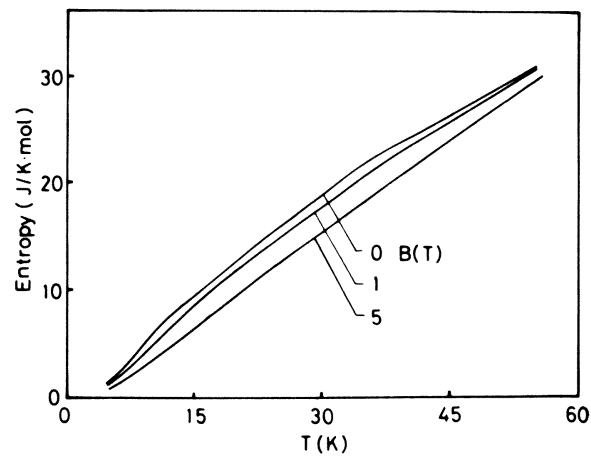

Fig. 10 Temperature dependences of the entropy of the same composite as in Fig. 9 in several magnetic fields.

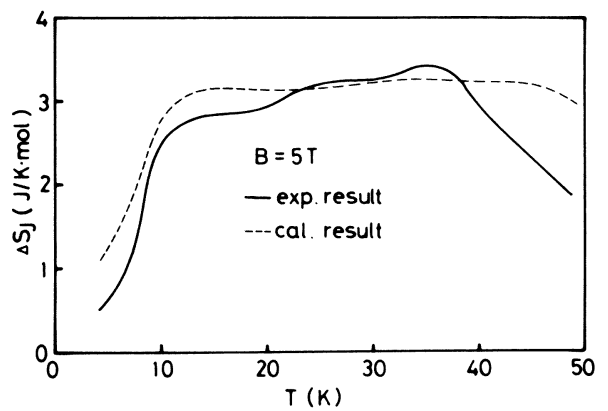

Fig. 11 Temperature dependence of the magnetic entropy change $\Delta S_{J}$ of the same composite as in Fig. 9. Dotted line shows the values of $\Delta S_{J}$ in Fig. 5, calculated from the experimental result of the $R \mathrm{Al}_{2}$ system.

\section{5. 考 察}

まず，今回得られた複合化物の磁気エントロピー変 化量 $\Delta S_{J}(T, B)$ について議論する。Fig. 11 に Fig. 10 から求められた $5 \mathrm{~T}$ の外磁場を加えた場合の $\Delta S_{J}$ $(T, B)$ が示されている。点線で示されたのが, $R \mathrm{Al}_{2}$ 系の結果に基礎を置いた複合化物の設計値であり, 実 線が実験值である。両者に相違が生じた原因は, 設計 の基礎としたのが $R \mathrm{Al}_{2}$ 系の結果であり, $R \mathrm{Al}_{2.15}$ 系で は, 部分的に $R \mathrm{Al}_{2}$ と $R \mathrm{Al}_{3}$ が固溶体を作ったために, この系の磁性が $R \mathrm{Al}_{2}$ の磁性と多少異ったことに起 因するものである。したがって, 実際の場合には, $R \mathrm{Al}_{2.15}$ 系の結果を基に設計すれば良いのであり, こ の差異は問題とするに足らない。

むしろここで強調したいのは，3種の磁性体を用い た層状複合化物でも，かなりの温度範囲に涉って $\Delta S_{J}$ の平坦化は可能であり, その相互のモル比を変えるこ とによって， $\Delta S_{J}$ の温度依存性を任意に制御できる ことである。

特に後者の任意の $\Delta S_{J}(T, B)$ が設計可能であると いう特性は, 非常に重要である。これまでの議論では, 理想エリクソンサイクルのみを考えてきた。しかし実 際にサイクル運転をする場合には, $1 \mathrm{cycle} / \mathrm{sec}$ 程度 の運転速度が予想されるが，このような速度で二つの 等磁場過程を経る際には, 準静的過程ではないので必 ボエントロピー生成を伴い, これが温度依存性を持つ ことも充分予測される。このようなサイクルにおいて は, 必ずしも Fig. 11 に示すような平坦な温度依存性 
を持つ $\Delta S_{J}(T, B)$ が適当であるとは限らず, 適当な 温度依存性を持たせる必要が生じる。このような場合 でも，複合化物を構成する磁性体の種類を増し，モル 比を適当に選べば，どのような要求にも対応できると いう利点をこの方法は持っている。

以上の考察から,このような複合化の方式は, 磁性 体の $S_{J}$ の優れた制御方式であると考えられるが，こ のことをより鮮明にするため, 最近エリクソン用とし て研究が始められているアモルファス磁性体の特性 ${ }^{9}$ との比較を行なっておく。アモルファス磁性体は，原 子配列の規則性を乱し, 磁性体中の磁気的相互作用, すなわち (1) 式中の $\lambda_{i j}$ の強度および符号に空間分布 を持たせたものであるということができる。したがっ てその相転移は, 均質磁性体の場合程は明瞭でなく, その $\Delta S_{J}(T, B)$ む, Fig. 2 の鋭いピークはなだらか なものに変る。しかし相転移温度は存在するので, 平 坦にはならない。

このような特性は, 確かに均質磁性体よりエリクソ ンに適しているように見える。しかしピークが存在す るため，2 章で述べた条件は満されない。また磁気工 ントロピーは, 磁気的相互作用と同程度の広い分布を 持つため, 冷凍域以外の領域にも多くの $\Delta S_{J}$ が存在 することになるので，活用できない $\Delta S_{J}$ も多い等の 欠点を持つことになる。これに対して複合化物は, 冷 凍域に大部分の $\Delta S_{J}(T, B)$ が集中され, 平坦化が容 易であるので，磁気エントロピーの制御方式としては より優れていると思われる。もちろん問題が全くない わけではなく, 層間の伝熱特性向上等, 幾つかの課題 があり, その研究は現在進行中である ${ }^{10)}$ 。

最後に，このような複合化磁性体の用途について簡 単にふれておく。特に低温工学材料に限ると, 蓄冷 材, あるいは超伝導の安定化材にその用途がある。低 温, 特に $10 \mathrm{~K}$ 以下の領域になると, 格子エントロピー が著しく低下するため，高い熱容量材を得るために は，新たな物理現象の応用を考えねばならなくなる。 この候補の一つに考えられるのが, 広い意味での磁性 体の相転移であるが, 特に相転移が協力現象である場 合には，熱容量は相転移温度で鋭いピークを作る。こ の特性は，温度制御には不適当であり，このピークを ある程度平坦化する方法としては, 本研究で述べた複 合化物が最適であると考えられる。このような意味か
らも,さらに種々の特性, 例えば伝熱特性の改善等も 含めた複合化磁性体の研究の重要性は, 今後益々増加 するものと思われる。

本研究は, 昭和60年, 61 年度の科学技術振興調整費 による「超伝導・極低温基盤技術に関寸る研究」の一 環として行なわれたものである。

\section{考文 献}

1）例えば,

C. Delpuech, R. Beranger, G. Bon Mardion, G. Claudet and A. A. Lacaze: Cryogenics 21 (1981) 579. H. Nakagome, N. Tanji, O. Horigami, T. Numazawa and T. Hashimoto: Adv. Cryog. Engr. 29 (1984) 583.

2) T. Hashimoto, T. Numazawa, Y. Watanabe, A. Sato, H. Nakagome, O. Horigami, S. Takayama and M. Watanabe: Proc. of ICEC 9 (1982) p. 26.

3) R. Li, T. Numazawa, T. Hashimoto, A. Tomokiyo, T. Goto and S. Todo: Adv. cryog. Engnr. 32 (1986) 287.

4) T. Hashimoto, T. Numazawa, M. Shiino and T. Okada: Cryogenics 21 (1981) 647.

5）特願 昭 59-060872

6) T. Hashimoto, K. Matsumoto, T. Kurihara, T. Numazawa, T. Tomokiyo, H. Yayama, T. Goto, S. Todo and M. Sahashi: Adv. Cryog. Engnr. 32 (1986) 279.

7) M. Sahashi et al. : J. Less. Comm. Metal 投稿中

8) A. Tomokiyo, H. Yayama, H. Wakabayashi, T. Kuzuhara, T. Hashimoto, M. Sahashi and K. Inomata; Adv. Cryog. Engnr. 32 (1986)

9）木村秀夫, 前田 弘, 佐藤古典, 深道和明：第 35 回低温工学研究発表会予稿集48頁。

10）佐橋政司, 丹生ひろみ, 猪俣浩一郎, 葛原徹, 橋本蘶洲：第35回低温工学研究発表会予稿集 57 頁。 